\title{
バイオマス新技術開発の インパクト分析手法の提案
}

\author{
奥田 隆明 1 - 秀島 聡 2 \\ 1 正会員 名古屋大学大学院助教授 環境学研究科 \\ 2学生員 名古屋大学大学院 環境学研究科
}

\begin{abstract}
バイオマスは優れた多くの特長を持つが，同時に様々な問題点を抱えるため十分に利活用されてい るとは言えない。 バイオマス利用を普及させるためには，これらの問題点を解決する新しい技術の開 発が必要不可欠である.ところが，新しい技術の開発には多額の資金が必要であるため，その技術が 実用化された時，環境と経済にどのようなインパクトを与えるのかについて事前に明らかにしておく 必要がある. 本研究では，木質バイオマスのガス化発電を取り上げ，そのインパクト分析を行うため の方法を提案した．また，岐阜県でパイロットモデルを作成し，これを用いて簡単な感度分析を行っ た. 分析の結果，発電効率を現状の $40 \%$ から $50 \%$ に向上させればバイオマス利用が始まり，さらに発 電効率が上昇すると林業などの生産にも影響を与える可能性を持つこと等を明らかにした。
\end{abstract}

Key Words: biomass, management of technology, computable general equilibrium model

\section{1. はじめに}

バイオマスは再生可能な資源で，それを燃焼させても 大気中の二酸化炭素を増加させない「カーボンニュート ラル」と呼ばれる特性を持ち, 地球温暖化の防止という 観点からその利用には大きな期待が寄せられている。 ま たその他にも，循環型社会の形成，新たな戦略的産業の 育成，農林漁業や農山漁村の活性化等の観点からも期待 されており，エネルギ一や製品としてこれを最大限活用 する社会を実現することが求められている ${ }^{1}$.

わが国は温暖・多湿な気候条件により，かなりのバイ オマス賦存量が見込まれている。しかし，現実には，そ の認知度が必ずしも高くないこと，エネルギ一や製品へ の変換技術の開発が不十分であること，収集が困難であ ること，その結果としてバイオマス利用の事業採算性が 悪いこと等の理由から，バイオマスの利用は必ずしも十 分に進んでいるとは言えない.

こうした現状を打開し，バイオマスの利活用を促進す るためには，新しい技術開発を行いエネルギー・製品へ の変換効率やバイオマスの収集効率を向上させていくこ とが必要不可欠である。しかし他方で，こうした新技術 開発を行うためには，多くの研究開発投資を必要とする ことも事実であり，公的な研究開発投資を含めてこれを 積極的に推進するためには，これらの新技術開発がバイ オマスの利活用を通して地域社会にどのようなインパク
トを与えるのかについて明らかにしていくことが必要で ある.

そこで本研究では，バイオマス新技術開発が地域社 会に与える影響を明らかにするインパクト分析手法を開 発することを目的とする．以下，続く2．ではバイオマ ス新技術開発の動向とそのインパクトの特徴について述 べる.また，3．では本研究で提案するインパクト分析 手法の詳細について説明する．さらに，4．では木質バ イオマスの利活用に積極的に取組んでいる岐阜県で作成 した簡単なパイロットモデルについて説明する. そして, 5.ではこのパイロットモデルを用いて感度分析を実施 し，モデルの挙動を確認した結果について報告する。

\section{2. バイオマス新技術開発とそのインパクト}

\section{（1）バイオマス利用技術}

バイオマスをエネルギーや製品として利用する技術は， 表 1 のように整理することができる．ここで，直接燃焼 とはバイオマスを直接燃焼させて熱を利用したり発電を 行ったりする技術を指寸。メタン発酵とはバイオマスを 嫌気性細菌に分解させてメタンを取り出す技術である. エステル化とは食用油などを調質し，ディーゼル然料と して使えるようにする技術である. ガス化とはバイオマ スを水素や一酸化炭素，メタンなどの可燃性ガスに分解 
する技術を指す．またエタノール発酵とは，木材などに 含まれるセルロースを糖化し，発酵させてエタノールを 得る技術である.

多くのバイオマスは「広く薄く」分布しており，木材 のように山間部に存在しているものも多い. そのため, これらのバイオマスを利用するための施設が大規模なも のになるとバイオマスを収集・運搬するためのコストが 大きくなり，採算性が低下寸る．そのため，小規模な施 設を分散して設置することが求められるが，現在，最も 多く利用されている直接燃焼では，小規模な設備で高い 発電効率を得ることには限界がある。こうした背景の中 で，バイオマスをガス化し，小型でも高効率を得られる ガスタービンやガスエンジンによって発電を行う方式を はじめ，新たな技術開発に大きな期待が寄せられている.

\section{（2）バイオマス新技術開発のインパクト}

では，これらの技術開発によってバイオマス利用が 普及すると，地域社会はどのようなインパクトを受ける のであろうか. 図1は「バイオマス・ニッポン総合戦 略」等を参考にしながら, バイオマス発電における新技 術開発が地域社会に与えるインパクトを整理したもので ある.

バイオマス新技術開発はバイオマス発電コストを低下 させ，そのコストは化石燃料等を利用した発電コストに 次第に近づいていく，これによってバイオマス発電は電 力市場において一定のシェアを獲得し, 化石燃料等を利 用した電力生産を減少させる. その結果, 既存の電力会 社が排出する二酸化炭素量を减少させることが可能にな る. 他方で, バイオマス発電が普及するとバイオマスの 需要も増加し，これまで廃棄物として処理されていたバ イオマスが有価物として市場取引の対象になることが予 想される. さらにバイオマス発電が本格化し，バイオマ 又需要が増加すると, この取引価格が次第に上昇してい く.そして，バイオマス価格の上昇はバイオマスの供給 をさらに増加させる。つまり，最初はこれまで廃棄物と
して処理されてきたバイオマスが市場に供給されるが， バイオマス価格の上昇に伴い，これまで放置されてきた 稲わらや間伐材，林地残材等の未利用バイオマスが積極 的に市場に供給されることが予想される.さらにバイオ マス価格が上昇すると, 飼料作物の栽培をはじめ, より 多くのバイオマスを生産するための産業が育成されるこ とになる.

こうしたバイオマスの生産は主に農林漁村で行われ るため，農林漁村には新たな雇用が創出されることにな る. そして, こうした雇用の創出は農林漁村に新たな消 費を生み出し，これによっても農林漁村の活性化に結び つ可能性を持っている.

\section{3. インパクト分析手法}

\section{(1) 分析手法の概要}

本研究では, バイオマス利活用が特に期待されてい る木質バイオマスを取り上げ，木質バイオマスを利用し た発電に関する新技術開発が地域社会に与える影響を定 量的に把握するための分析モデルを開発する. 従来, 新 技術開発が地域社会に与えるインパクトを分析する手法 としては，産業連関分析を用いた方法 ${ }^{2), 33}$ や応用一般均 衡モデルを用いた方法 ${ }^{4}$ が幾つか提案されてきている. しかし, これらの研究は何れも, いわゆる動脈産業にお ける新技術開発のインパクトを分析するものであり，バ イオマス利用のような静脈産業における新技術開発のイ ンパクトを分析することを目的としたものではない.

2. (2)でも説明した通り, バイオマス新技術が開発され ると，これまで無価物として扱われてきたバイオマスが 有価物として市場取引の対象となる可能性を持つ. そし て，これが地域社会に多くのインパクトを与えることが 予想されるため，こうした静脈産業における新技術開発 のインパクトを分析するためには，これらのメカニズム を十分考慮した新たな分析手法の開発が必要となる.

\section{表 1 バイオマス利用技術}

\begin{tabular}{|l|l|l|}
\hline \multirow{2}{*}{} & \multicolumn{2}{|c|}{ 用途 } \\
\cline { 2 - 3 } & エネルギー & 製品 \\
\hline \multirow{4}{*}{ 実用化 } & 直接燃焼 & 堆肥化 \\
& 炭化 & 飼料化 \\
& エンン発酵 & 再生木質ボー \\
& エステル化 & ド \\
\hline \multirow{3}{*}{ 開発中 } & ガス化 & ホタノー質プラス \\
& エタク & チッ発 \\
& 酵 & \\
\hline
\end{tabular}

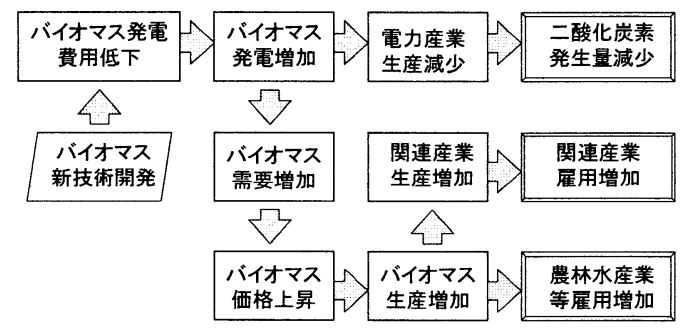

図 1 バイオマス利用の普及によるインパクト 


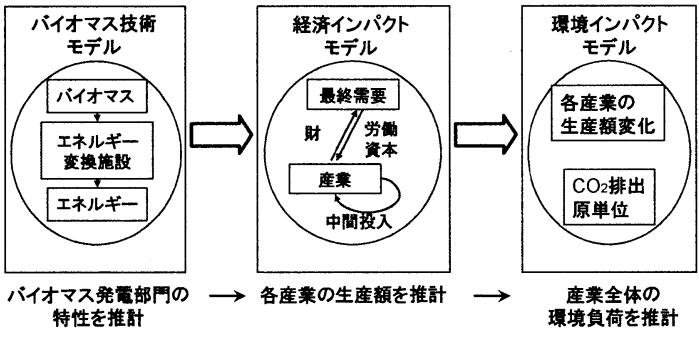

図 2 モデルの全体構成

\section{（2）モデルの全体構成}

本研究で提案するモデルは，1)経済インパクトモデル， 2)バイオマス技術モデル，3）環境インパクトモデルの 3 つのサブモデルから構成される(図2)。1)経済インパク トモデルは，新技術開発によって新たなバイオマス利用 産業が登場したとき，対象とする地域経済全体が受ける インパクトを分析する. ところが，こうしたバイオマス 利用産業は既存の産業ではないため，これを経済インパ クトモデルに組み込んでシミュレーションを行うには新 技術開発によって生まれるバイオマス利用産業のパフォ 一マンス（投入と産出）を別途与える必要がある．2)バ イオマス技術モデルでは，こうした新しいバイオマス利 用産業のパフォーマンスを求める. さらに，3)環境イン パクトモデルでは, 経済インパクトモデルによって求め られた各産業部門の生産量の変化から，新技術開発によ って地域社会から排出される環境負荷がどの程度変化す るのかを明らかにする。

\section{（3）経済インパクトモデル}

\section{a) 基本的な設定}

木質バイオマスの多くは，林業や製材・製紙業，建設 業等が生産活動を行うときに副産物として排出される. 本研究では，こうした木質バイオマスを利用して電力生 産を行うバイオマス発電産業を考える，バイオマス発電 産業は，現在，廃衰物として処理されている木質バイオ

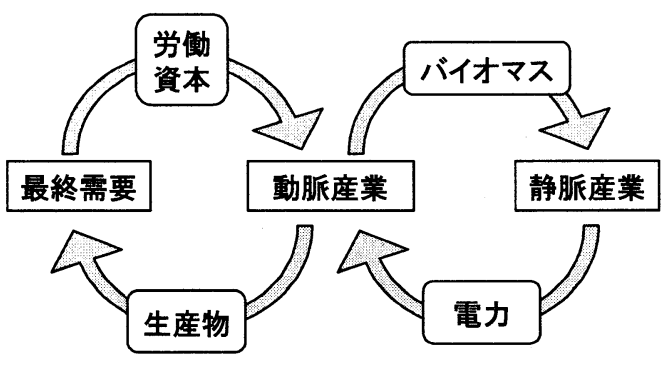

図3 経済主体と取引対象の関係
マスを利用して電力生産を行う静脈産業である（図3）. この経済インパクトモデルでは, 最終需要部門が労衝・ 資本を産業部門に供給し，産業部門が生産物を最終需要 部門に供給するという通常の経済循環の他に，動脈産業 が排出したバイオマスを利用してバイオマス発電産業が 電力を供給するという新たな物質循環を考えることにす る.

具体的には，動脈産業として，電力部門を含む $n$ 種 類の産業部門を考える. また最終需要部門としては, 域 内の最終需要部門と域外の最終需要部門を考えることに する.さらに静脈産業としてはバイオマス発電部門を想 定する．他方，取引対象としては， $n$ 部門の産業部門 がそれぞれ生産する $n$ 種類の生産物を考える.また, 生産要素としては, 資本と労働を考える. その他に, 動 脈産業が排出し，バイオマス発電部門に投入されるバイ オマスを考えることにする．また，バイオマス発電部門 が生産する電力は電力部門が生産する電力と同質とみな されるものとする.

\section{b) 電力部門と産業部門}

ある産業 $j$ は, 労働 $L_{j}$, 資本 $K_{j}$, 域内財 $D_{i j}$, 移 入財 $M_{i j}$ から生産物 $X_{j}$ とバイオマス $B_{j}$ を生産するも のとする. このとき, 電力部門と産業部門は, 次の利潤 最大化問題に従って行動するものとする.

$$
\begin{array}{ll}
\operatorname{Max} & \pi_{j}=p_{j} X_{j}+p^{B} B_{j}- \\
& \left(\sum_{i} p_{i} D_{i j}+\sum_{i} p_{i}^{M} M_{i j}+p^{L} L_{j}+p^{K} K_{j}\right) \\
\text { s.t. } \quad f_{j}\left(X_{j}, B_{j}, D_{i j}, M_{i j}, L_{j}, K_{j}\right)=0 \\
\quad X_{j}, B_{j}, D_{i j}, M_{i j}, L_{j}, K_{j} \geq 0
\end{array}
$$

ここで， $\pi_{j}$ : 第 $j$ 産業の利潤, $p_{j}$ : 第 $j$ 生産物の価 格, $p^{B}$ : バイオマスの価格, $p_{i}^{M}$ : 第 $i$ 移入財の価格, $p^{L}$ : 労働の価格, $p^{K}$ : 資本の価格

生産関数 $f_{j}$ については, 図4に示すような多段階の生

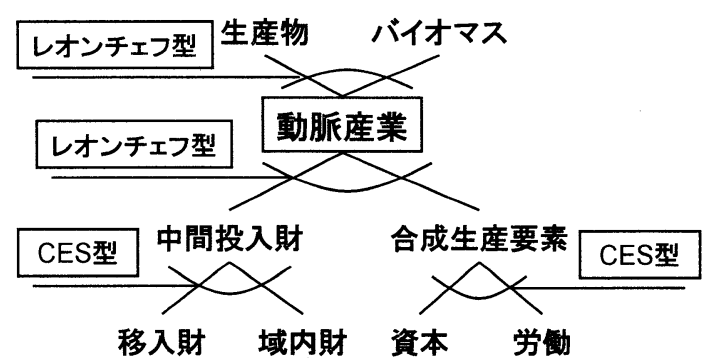

図4 電力部門と産業部門の生産関数 
産関数を仮定する.つまり, まず労働と資本, 域内財と 移入財がそれぞれ CES 型関数で結合され，次にそれぞれ の合成財がレオンチェフ型関数で結合されるものとする. こうした生産関数は通常の応用一般均衡モデルで仮定さ れる生産関数と全く同じである. 本研究ではこれに副産 物としてのバイオマスを考慮するために, さらに生産物 とバイオマスがレオンチェフ型関数で変形されることを 仮定する.つまり, 産業部門は一定の生産物を生産する ために一定のバイオマスを排出する必要があることを仮 定する.

\section{c) バイオマス発電部門}

バイオマス発電部門は, 労働 $L_{N}$, 資本 $K_{N}$, 域内財 $D_{i N}$, 移入財 $M_{i N}$ およびバイオマス $B$ から電力 $X_{P}$ を 生産するものとする.このとき, バイオマス発電部門も 次の利潤最大化問題に従って行動するものとする.

$\operatorname{Max} \pi_{N}=p_{P} X_{N}-$

$$
\left(\sum_{i} p_{i} D_{i N}+\sum_{i} p_{i}^{M} M_{i N}+p^{L} L_{N}+p^{K} K_{N}+p^{B} B\right)
$$

s.t. $f_{N}\left(X_{N}, D_{i N}, M_{i N}, L_{N}, K_{N}, B\right)=0$

$$
X_{N}, D_{i N}, M_{i N}, L_{N}, K_{N}, B \geq 0
$$

ここで, $p_{P}:$ 電力の価格

バイオマス発電部門の生産関数 $f_{N}$ についも, 図 5

のような多段階の生産関数を仮定する.つまり，労働と 資本，域内財と移入財がそれぞれ CES 型関数で結合さ れ，それぞれの合成財がレオンチェフ型関数で結合され るものとする. このとき, 一定のバイオマス発電を行う ためには一定のバイオマスを投入が必要であるものとし， バイオマスについてもこのレオンチェフ型関数で結合さ れるものとする. なお, レオンチェフ型関数のパラメー タについては新技術の開発によって変化するため, 後述 するバイオマス技術モデルによって求めるものとする.

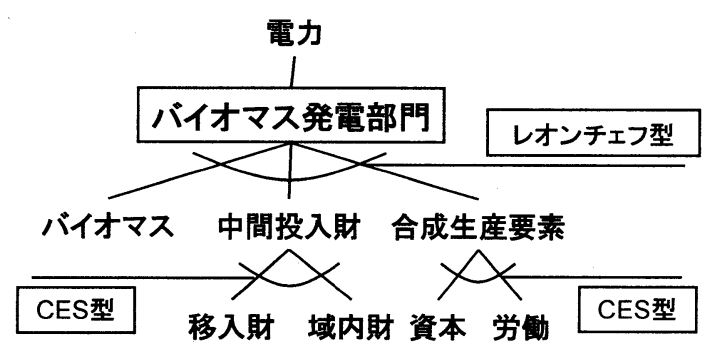

図5 バイオマス発電部門の生産関数

\section{d) 最終需要部門}

最終需要部門は, 域内最終需要部門と域外最終需要部 門の 2 部門である. 域内最終需要部門は, 労働と資本を 供給し, 産業部門が生産する生産物, 電力部門とバイオ マス発電部門が生産する電力を購入するものとする．ま た, 域外最終需要部門は, 当該地域への輸出による収入 で輸入を行っているものとする．また，それぞれの部門 は効用最大化問題に従うものとする. さらに, 効用関数 についても, 通常の応用一般均衡モデルと同様に, CES 型とコブ=ダグラス型関数を組合せた多段階の効用関数 を用いる。

\section{e) 市場条件}

労働, 資本, 生産物の市場ではそれぞれ需給均衡が成 立するものと仮定する.ところが，バイオマスについて は, 廃棄物として市場取引の対象にならない場合と, 有 価物として市場取引の対象になる場合の 2 つ状態を考 える必要がある. 図6はバイオマス市場における需要曲 線と供給曲線を表したものである. バイオマス発電部門 が十分な生産を行わない段階では，価格がゼロであって も供給（点 B) が需要（点 A）より大きい. しかし, 新 技術開発によってバイオマス発電部門が多くの生産を行 うようになると, バイオマスの需要が増加し, 需要曲線 が右方向にシフトすることになる（曲線 $D^{\prime}$ ）。 その結 果, バイオマスに正の価格が付いて, バイオマスが市場 で取引されることになる（点 C) 。そしてバイオマスに 正の価格が付くと，今まで放置されていた間伐材等の未 利用バイオマスの利用が進み, さらに価格が上昇すれば, 積極的にバイオマスを生産するような状況が生み出され ることになる.

バイオマス市場のこうした状況は次の相補性条件を 用いて定式化することができる.

$$
\begin{cases}p^{B}=0, & \sum_{j} B_{j} \geq B \\ p^{B}>0, & \sum_{j} B_{j}=B\end{cases}
$$

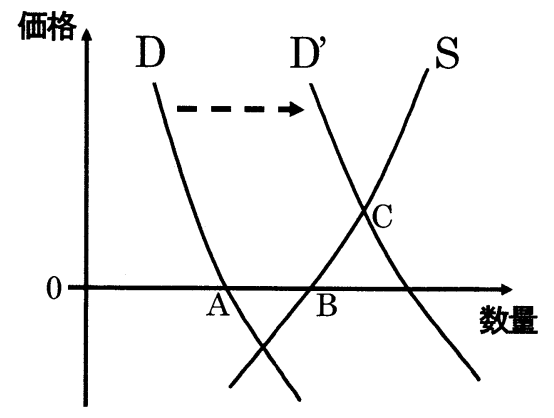

図6 新技術開発がバイオマス市場に与える影響 


\section{f）均衡条件式とその解法}

以上より, 経済インパクトモデルの均衡条件式として 付録の方程式体系が得られる. したがって, 式(A1)〜 (A33) から, 変数 $X_{j} \sim p^{B}$ を求めればよいことになる. このとき, 式(A1)〜 (A33) は相補性条件を含む混合相補 性問題である. 相補性問題の解法についてはメリット関 数を用いた方法等, 応用数学の分野で多くの研究が行わ れている ${ }^{5)}$. 本研究では, 最適化問題の解析ソフト GAMS の混合相補性問題用ソルバーPATH を用いてこの混合相 補性問題の解を求めた.

\section{（4）バイオマス技術モデル}

バイオマス技術モデルでは，上述したバイオマス発 電部門のレオンチェフ型生産関数のパラメータ（投入係 数）を求める. このパラメータ（投入係数）はバイオマ ス発電の費用を収入で除すことにより求めることができ る.

バイオマス発電の費用として，1)原料購入費（中間財 投入），2)人件費（労働投入），3)減価償却費（資本投 入）を考える. このとき, 原材料購入費用については次 式を用いて求める.

原料購入費 $=$ 原料投入量 $\times($ 原料単価 + 収集単価 $)$

他方, バイオマス発電の収入としては，1)売電収入, 2)補助金を考える.このとき, 売電収入については次式 を用いて求める.

売電収入二原料投入量 $\times$ 原料発熱量 $\times$ 冷ガス効率 $\times$ 発電効率 $\times(1$-所内率 $) \times$ 電力単価 (5)

このバイオマス技術モデルを用いると，例えば発電 機の技術開発によって発電効率が上昇した場合には, 式 (5)の発電効率の值を変化させ，新技術開発後の収入を 求める. また，収集システムに関する技術開発によって 収集単価が低下した場合には, 式(4)の収集単価の值を 変化させ，新技術開発後の費用を求める. そして，こう して求めた新技術開発後の費用と収入から, レオンチェ フ型生産関数のパラメータ (投入係数) を求める.

\section{（5）環境インパクトモデル}

環境インパクトモデルでは, 新技術開発によりバイ オマス発電が普及すると, 地域社会全体から排出される 環境負荷がどの程度変化するのかについて分析する.こ のとき, バイオマス発電の普及によって環境が受けるイ ンパクトとしては, 化石然料の使用量の低下, その結果 としての二酸化炭素排出量の減少, 廃棄物系バイオマス
が利用されることによる廃棄物排出量の減少等が考えら れる.これらの環境負荷の変化は, バイオマス発電の普 及によって地域社会の生産が変化することによって引き 起こされる. そのため, 経済インパクトモデルから求め られる生産額の変化に各産業の単位生産当たりの環境負 荷を乗じることでその大きさを求める. 例えば，二酸化 炭素の排出量については, 経済インパクトモデルから求 められた各産業の生産額の変化に, 各産業の単位生産当 たり二酸化炭素排出量を乗じることで，産業から排出さ れる二酸化炭素排出量の変化を求める.

\section{4. 岐阜県におけるパイロットモデルの開発}

\section{(1) 対象地域の設定}

本研究では岐阜県においてパイロットモデルを作成 し，この分析手法を用いた簡単なインパクト分析を試み た. 対象地域として岐阜県を選んだのは, 山林の面積が 大きく，林業生産のシェアが全国平均に比べて高いこと， その結果, 木質バイオマスの賦存量も多く, バイオマス 発電の普及が地域社会に大きなインパクトを与える可能 性を持つこと，また，これまでにも「岐阜県新エネルギ ービジョン」や「木質バイオマスエネルギー導入モデル 基本計画」を策定する等，木質バイオマスの利活用に関 する多くの取組みを実施していること，そして，木質バ イオマスに関する基礎的な情報が比較的入手しやすいこ となどが挙げられる.

\section{（2）経済インパクトモデルの作成}

経済インパクトモデルの動脈部門については，当該 地域の産業連関表を用いてキャリブレーションを行うこ とができる. 本研究では, 平成 12 年に推計された岐阜 県産業連関表 のを用いて産業部門・電力部門, 域内最終 需要部門・域外最終需要部門のキャリブレーションを行 った. このとき, 平成 12 年の岐阜県産業連関表は産業 分類は 104 分類であるが, これを木質バイオマスに関連 する産業を中心に集計して用いた。つまり，産業分類を， 1)農水産業，2)林業，3)釷業，4)製材・製紙，5)建設，6) 第二次産業, 7)電力, 8)第三次産業の 8 部門とした.こ こで，製材・製紙，建設を独立させたのは，この 2 部門 が産業廃棄物として木質バイオマスを多く排出している ためである.

また, 各産業のバイオマス排出量については, 岐阜 県廃棄物処理計画資料 别及び岐阜県間伐材利用事例集 $(\text { 案 })^{8)}$ の值を用いた. さらに, バイオマス発電部門の投入 と産出については，(3)バイオマス技術モデルの作成の 部分で説明する. 
その他, 経済インパクトモデルには, 労働と資本の 代替弾性值, 域内財と移入財の代替弾性值が必要となる が，これらの值については代表的な応用一般均衡モデル である世界貿易モデル(GTAP) $)^{9)}$ で採用されている日本の 值を参考として設定した.

\section{（3）バイオマス技術モデル}

バイオマス技術モデルでは，現在，事業化されている バイオマス発電の費用と収入に関する情報を用いて，キ ヤリブレーションを行った.

バイオマス発電の費用のうち，減価償却費，人件費， 原料購入費については, 「廃棄物発電導入マニュアル改 訂版（資料編）」(NEDO) ${ }^{10)}$ の発電システムデータベー スに掲載されている発電システムの受注実績のデータを 参考にして設定した. その他, バイオマスの収集費用に ついて「平成 12 年度バイオマス資源の利用手法に関 する調査」(林野庁 $)^{11)}$ を参考にして設定した.

また，バイオマス発電の収入を算出するためのパラメ 一タについては，「やまぐち森林バイオマスエネルギ

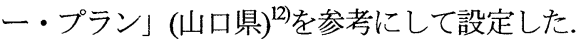

\section{（4）環境インパクトモデル}

環境インパクトモデルでは単位生産当たりの環境負 荷排出量の值が必要となる. このとき, 二酸化炭素の排 出量については, 2000 年産業連関表による環境負荷原 単位データブック(3EID)104 部門版 ${ }^{12)}$ に基づき, 8 分類の 生産額と二酸化炭素排出量を求め, その值から求めた.

また, バイオマス発電部門の二酸化炭素排出量原単 位についてはゼロとみなした. 本来, バイオマス発電部 門はバイオマスの燃焼に伴い二酸化炭素を排出する.し かし, これらの二酸化炭素はバイオマスが生産される時 に光合成によって大気中から吸収したものである. その ため, バイオマス発電に投入したバイオマスと同量のバ イオマスを植林等によって生産すれば, バイオマス発電 部門から排出される二酸化炭素排出をゼロとみなすこと ができる．また，産業連関表の仮定により，バイオマス の収集等に伴って排出される二酸化炭素は輸送サービス を供給する部門が排出するため, バイオマス発電部門に は計上しない.

\section{5. パイロットモデルの感度分析}

\section{（1）ケース設定}

本研究では, 岐阜県で作成したパイロットモデルの挙 動を確認するため, 新技術開発によってバイオマス発電 部門の発電効率が向上した場合に，岐阜県がどのような
インパクトを受けるのかについて簡単な感度分析を行っ た. 現在, バイオマス発電の発電効率は $40 \%$ 程度であ る.これに対してセラミックガスタービンをはじめとす るバイオマス新技術開発が実現すれば，その発電効率は 50\%程度に向上すると言われている. さらに, 燃料電池 とガスタービンのハイブリッドシステム等の開発目標に は, 発電効率を 70\%まで向上させようとするものも見 られる. そこで, 本研究では発電効率が $40 \%$ の場合(ケ ース 1)，発電効率が $50 \%$ まで向上した場合(ケース 2)， 発電効率が 60\%まで向上した場合(ケース 3), 発電効率 が 70\%まで上昇した場合(ケース 4)の 4 つのケースを設 定し，それぞれのインパクトについて岐阜県のパイロッ トモデルを用いて感度分析を行った。

\section{(2) バイオマス発電の普及}

図 7 は, バイオマス発電の発電効率の変化に伴って バイオマス発電の年間発電量がどのように変化するのか をシミュレーションした結果である. 発電効率が $40 \%$ の現状ではバイオマス発電量はゼロとなる. しかし, 新 技術開発により発電効率が $50 \%$ まで向上すれば，バイ オマス発電量は 23,000 万 $\mathrm{kWh}$ (既存の電力部門の $1.6 \%$ ）となった. さらに, 発電効率が $60 \%, 70 \%$ に上 昇すると, バイオマス発電量は 28,000 万 $\mathrm{kWh}$ (既存の

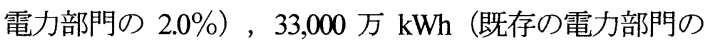
2.3\%）まで増加した。 このように新技術開発によって バイオマス発電の発電効率を上げることができれば, 次 第にバイオマス発電が普及する可能性を持っていること, 中でも, 発電効率を $40 \%$ から $50 \%$ 程度まで上昇させる ことができれば，バイオマス発電は急速に普及していく 可能性があること等が明らかになった。

\section{(3) 経済インパクト}

図8 は, バイオマス発電の発電効率の変化に伴って バイオマスの価格がどのように変化し，また，林業生産 がじのように変化するのかを分析した結果である. 上述

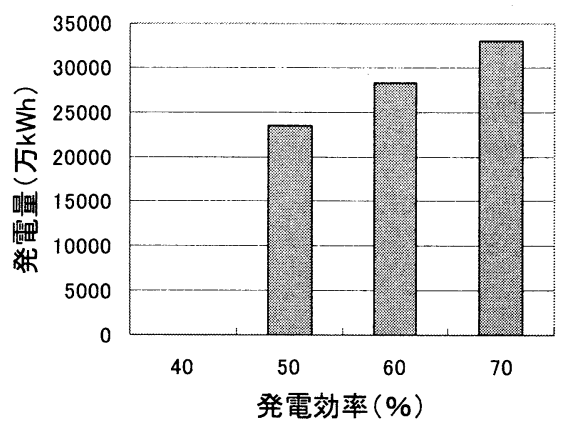

図 7 バイオマス発電効率と発電量の変化 
した通り，発電効率が $40 \%$ の現状では，バイオマスの 供給は需要を上回り, 市場取引の対象とはならない（価 格はゼロである）。しかし，発電効率が 50\%程度まで 上昇すると，バイオマスに価格が付いて市場取引の対象 となる.さらに, 発電効率が $60 \%$ まで向上するとバイ オマスは 6,000 円/t の価格で取引され, 電効率が $70 \%$ ま で上昇すると，その価格は 13,000 円/ $/$ まで上昇した.

他方で，こうしたバイオマス価格の上昇によって木 質バイオマスを供給する林業の生産が増加する. 発電効 率が $50 \%$ の段階では林業生産の増加率は $0.1 \%$ と小い が，発電効率が $60 \% ， 70 \%$ まで向上すると，林業生産 の増加率は急速に高くなり，1.0\%，2.4\%まで増加した。 つまり，(2)でも説明した通り，バイオマスの普及という 観点から考えると, 発電効率を $50 \%$ 程度まで上昇させ ることが重要であるが, 林業生産をはじめとする関連産 業にも大きなインパクトを与えるためには，発電効率を 60\%〜 70\%まで向上させ, バイオマスがある程度の価格 で取引されるような段階に入らなければならないことが 明らかにされた。

\section{（4）環境インパクト}

図 9 は, バイオマス発電の発電効率の変化に伴って 岐阜県の産業全体が排出する二酸化炭素がどのように変 化するのかを示したものである. (2)でも説明した通り， バイオマス発電の発電効率が $40 \%$ から $50 \%$ まで上昇す ると, バイオマス発電量が急速に増加する. これに伴つ て競合する既存の電力部門での電力生産が減少し, 二酸 化炭素の排出量が減少する. 他方で, (3)でも説明した通 り, 発電効率が $50 \%$ の段階ではバイオマス生産に関連 する産業へのインパクトは小さく, これによって新たに 排出される二酸化炭素量は少ない, その結果, 岐阜県の 産業全体から排出される二酸化炭素量は 28,000 炭素 $\mathrm{t}$ （全産業の排出量の $0.5 \%$ ）減少する. さらにバイオマ ス発電の発電効率が $60 \%, 70 \%$ まで上昇すると，特に

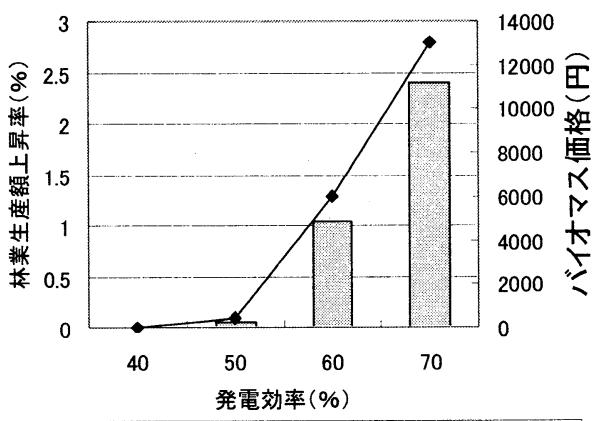

林業生産額上昇率 ーーバイオマス価格

図8 バイオマス価格と林業生産の変化
バイオマスの生産に関連する産業で生産が増加し，これ らの産業から排出される二酸化炭素量は増加する. しか し，化石燃料を投入して行われる既存の電力部門の生産 が減少し，これに関連する産業も含めて二酸化炭素の排 出量は減少する. その結果, 岐阜県の産業全体では, 発 電効率 60\%の場合，二酸化炭素の排出量は 33,000 炭素 $\mathrm{t}$ の減少, さらに, 発電効率 70\%の場合には, 38,000 炭素 $\mathrm{t}$ 減少する.このように二酸化炭素の排出削減量を見て も, バイオマス発電の発電効率を $50 \%$ まで减少させる と, 二酸化炭素の排出量は大きく減少することが明らか になった。

\section{6. おわりに}

本研究では，バイオマス新技術開発が地域社会に与え るインパクトを把握するための分析手法の提案を行った. このインパクト分析手法の特長は, バイオマス発電部門 のような静脈産業での新技術開発が地域社会に与える影 響を分析できる点にある. バイオマス発電部門のような 静脈産業で新技術が開発されると, 化石燃料を利用した 既存の電力部門の生産の一部がバイオマス発電部門の生 産によって置き換わるだけでなく, バイオマスの需要が 増加し，これまで廃棄物として扱われていたバイオマス が有価物として市場取引の対象となる.ささら，これに よって新たなバイオマスの生産が始まり，これが関連産 業にも影響を及ぼし，地域全体に多くのインパクトを与 える. 本研究で提案したインパクト分析手法では, バイ オマス市場を相補性問題として定式化することにより， バイオマスが無価物から有価物に転換する状態を扱うこ とが可能になった.

また, 論文の後半では, このインパクト分析手法を岐 阜県に適用し, そのパイロットモデルを作成した. そし て, このパイロットモデルの感度分析を行い, モデルの

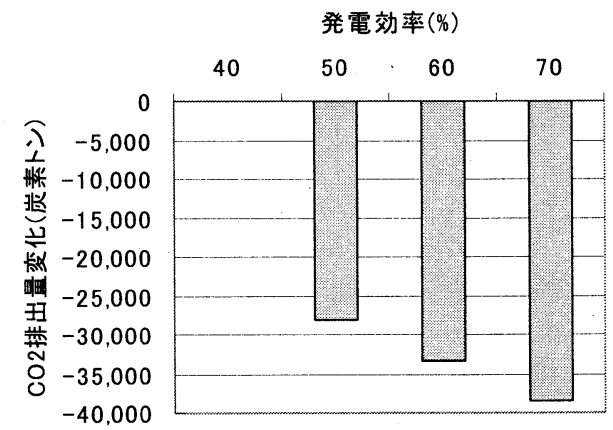

図9 バイオマス発電効率と二酸化炭素排出量の変化 
挙動を確認した. その結果, バイオマス発電部門の発電 効率が現状の $40 \%$ から $50 \%$ 程度まで上昇すると, バイ オマス発電が急速に普及する可能性があること，しかし， 発電効率を $50 \%$ まで上げても, バイオマスを生産する 産業へのインパクトは比較的少ないこと, これらの産業 にもインパクトを与えるためには, バイオマス発電の発 電効率をさらに向上させる必要があることなどを明らか にすることができた.

しかし, 本研究では岐阜県で簡単なパイロットモデル を作成し, その感度分析を行った段階に止まっているた め, これを現実的な政策評価に結び付けていくためには, さらに多くの課題を解決しなければならない. 例えば, 現実の研究開発投資のインパクト分析を行うためには, 新技術導入に必要な費用を詳細に検討し，これをバイオ マス技術モデルの入力変数として与える必要がある.こ うした新技術導入の費用については, 新技術の普及に伴 って量産効果が発揮され, 設備の価格が急速に低下する ことも考えられる. また, こうした量産効果を生み出す ために，新技術の普及段階に公的補助を実施することも 考えられ，こうした補助の効果などについても明らかに しなければ，新技術導入に必要な費用のシナリオを与え ることは難しい. 今後は, これらに関してより現実的な シナリオを与えることで, さらに現実的な政策評価が可 能になるものと考えている.

\section{付録 経済インパクトモデルの方程式体系}

\section{＜電力部門と産業部門＞}

$$
\begin{aligned}
& X_{j}=\frac{\bar{X}_{j}}{\bar{Y}_{j}} \cdot Y_{j} \\
& B_{j}=\frac{\bar{B}_{j}}{\bar{Y}_{j}} \cdot Y_{j} \\
& Z_{i j}=\frac{\bar{Z}_{i j}}{\bar{Y}_{j}} \cdot Y_{j} \\
& D_{i j}=\frac{\bar{D}_{i j}}{\bar{Z}_{i j}} \cdot\left(\frac{p_{i j}^{Z}}{p_{i}}\right)^{\sigma_{i}} \cdot Z_{i j} \\
& M_{i j}=\frac{\bar{M}_{i j}}{\bar{Z}_{i j}} \cdot\left(\frac{p_{i j}^{Z}}{p_{i}^{M}}\right)^{\sigma_{i}} \cdot Z_{i j} \\
& F_{j}=\frac{\bar{F}_{j}}{\bar{Y}_{j}} \cdot Y_{j}
\end{aligned}
$$

$$
\begin{aligned}
& L_{j}=\frac{\bar{L}_{j}}{\bar{F}_{j}} \cdot\left(\frac{p_{j}^{F}}{p^{L}}\right)^{\sigma_{j}} \cdot F_{j} \\
& K_{j}=\frac{\bar{K}_{j}}{\bar{F}_{j}} \cdot\left(\frac{p_{j}^{F}}{p^{K}}\right)^{\sigma_{j}} \cdot F_{j} \\
& p_{j} \cdot X_{j}+p^{B} \cdot B_{j}=\sum_{i} p_{i j}^{Z} \cdot Z_{i j}+p_{j}^{F} \cdot F_{j} \\
& p_{i j}^{Z} \cdot Z_{i j}=p_{i} \cdot D_{i j}+p_{i}^{M} \cdot M_{i j} \\
& p_{j}^{F} \cdot F_{j}=p^{L} \cdot L_{j}+p^{K} \cdot K_{j}
\end{aligned}
$$

\section{〈バイオマス発電部門〉}

$$
\begin{aligned}
& Z_{i N}=\frac{\bar{Z}_{i N}}{\bar{X}_{N}} \cdot X_{N} \\
& D_{i N}=\frac{\bar{D}_{i N}}{\bar{Z}_{i N}} \cdot\left(\frac{p_{i N}^{Z}}{p_{i}}\right)^{\sigma_{i}} \cdot Z_{i N} \\
& M_{i N}=\frac{\bar{M}_{i N}}{\bar{Z}_{i N}} \cdot\left(\frac{p_{i N}^{Z}}{p_{i}^{M}}\right)^{\sigma_{i}} \cdot Z_{i N}
\end{aligned}
$$

$F_{N}=\frac{\bar{F}_{N}}{\bar{X}_{N}} \cdot X_{N}$

$$
\begin{aligned}
& L_{N}=\frac{\bar{L}_{N}}{\bar{F}_{N}} \cdot\left(\frac{p_{N}^{F}}{p^{L}}\right)^{\sigma_{N}} \cdot F_{N} \\
& K_{N}=\frac{\bar{K}_{N}}{\bar{F}_{N}} \cdot\left(\frac{p_{N}^{F}}{p^{K}}\right)^{\sigma_{N}} \cdot F_{N} \\
& B=\frac{\bar{B}}{\bar{X}_{N}} \cdot X_{N} \\
& p_{P} \cdot X_{N}=\sum_{i} p_{i N}^{Z} \cdot Z_{i N}+p_{N}^{F} \cdot F_{N} \\
& p_{i N}^{Z} \cdot Z_{i N}=p_{i} \cdot D_{i N}+p_{i}^{M} \cdot M_{i N} \\
& p_{N}^{F} \cdot F_{N}=p^{L} \cdot L_{N}+p^{K} \cdot K_{N}
\end{aligned}
$$

\section{<域内最終需要部門 $>$}

$$
\begin{aligned}
& I=p^{L} \cdot L+p^{K} \cdot K \\
& Z_{i H}=\frac{\bar{Z}_{i}^{H}}{\bar{I}} \cdot \frac{I}{p_{i H}^{Z}}
\end{aligned}
$$




$$
\begin{aligned}
& D_{i H}=\frac{\bar{D}_{i H}}{\bar{Z}_{i H}} \cdot\left(\frac{p_{i H}^{Z}}{p_{i}}\right)^{\sigma_{i}} \cdot Z_{i H} \\
& M_{i H}=\frac{\bar{M}_{i H}}{\bar{Z}_{i H}} \cdot\left(\frac{p_{i H}^{Z}}{p_{i}^{M}}\right)^{\sigma_{j}} \cdot Z_{i H} \\
& p_{i H}^{Z} \cdot Z_{i H}=p_{i} \cdot D_{i H}+p_{i}^{M} \cdot M_{i H}
\end{aligned}
$$

\section{<域外最終需要部門 $>$}

$$
\begin{aligned}
& E=\sum_{i} \sum_{j} p_{i}^{M} \cdot M_{i j}+\sum_{i} p_{i}^{M} \cdot M_{i B} \\
&+\sum_{i} p_{i}^{M} \cdot M_{i H} \\
& D_{i E}=\frac{\bar{D}_{i E}}{\bar{E}} \cdot \frac{E}{p_{i}}
\end{aligned}
$$

$$
\begin{aligned}
& <\text { 市場条件> } \\
& X_{i}=\sum_{j} D_{i j}+D_{i B}+D_{i H}+D_{i E} \quad(i \neq P) \\
& X_{P}+X_{N}= \\
& \quad \sum_{j} D_{P j}+D_{P B}+D_{P H}+D_{P E} \\
& L=\sum_{j} L_{j}+L_{B} \\
& K=\sum_{j} K_{j}+K_{B} \\
& \left\{\begin{array}{l}
p^{B}=0, \quad \sum_{j} B_{j} \geq B \\
p^{B}>0, \quad \sum_{j} B_{j}=B
\end{array}\right. \\
& p_{i}^{M}=1
\end{aligned}
$$

ここで，上付きの変数（例えば， $\bar{X}_{j}$ ）は基準均衡時の 值を示す.

\section{参考文献}

1) 農林水産省他 : バイオマス・ニッポン総合戦略,2002

2) 鬼木甫: 新しい情報通信技術と産業連関分析,イノベ ーション\& 1-Oテクニーク,第1巻,第1号,1989.

3) 宍戸俊太郎 : 技術革新とIOO分析, イノベーション\& IOテクニーク,第1巻,第2号,1990.

4) 新保豊・富島正雄・浅川秀之 : 光ファイバ一整備に よる経済波及効果とポストe-Japan戦略への示唆,イノ ベーション\&1ーOテクニーク,第13巻,第3号,2005.

5) 福島雅夫 : 均衡モデル : 相補性問題への招待,オペレ ーションズ・リサーチ,41,no.6,1996

6) 岐阜県: 平成12年岐阜県産業連関表,2004

7) 岐阜県 : 岐阜県廃棄物処理計画（資料編,産業廃棄物 編) 2000

8) 岐阜県 : 岐阜県間伐材利用事例集(案),2002

9) 川崎研一: 応用一般均衡モデルの基礎と応用, 日本評 論者, 1999

10).新エネルギー・産業技術総合開発機構 : 廃棄物発電 導入マニュアル（改訂版）,2002

11)林野庁 : 平成12年度バイオマス資源の利用手法に関 する調查, 2000

12)山口県 : やまぐち森林バイオマスエネルギー・プラ ン,2002

13) 南齋規介・森口祐一・東野達 : 2000 年産業連関表に よる環境負荷原単位データブック(3EID)104部門版,独 立行政法人国立環境研究所 地球環境研究センタ $-2002$

\section{A METHOD FOR IMPACT ANALYSIS OF NEW BIOMASS TECHNOLOGIES}

\section{Takaaki OKUDA and Satoshi HIDESHIMA}

The biomass utilization is not common due to insufficient development of its technology. To promote the utilization and benefits of biomass, it is necessary to develop a new technology and ensure its high economical efficiency. As heavy investments are required for the development of new technologies, it is necessary first to clarify the influence economy and the environment by the technology. Then, we suggest the method of analyzing the impacts of the new technology concerning biomass. We also analyzed its potential for Gifu Prefecture. The result shows that when a supplementary rate of the facilities construction cost is $50 \%$, biomass utilization begins if the power generation efficiency rises to $50 \%$. If the efficiency rises further, this will have a positive impact on the forestry production. 